\title{
Recurrent meningitis and persistence of craniopharyngeal canal: case report
}

\author{
D. Pinilla-Arias; J. Hinojosa; J. Esparza and A. Muñoz*
}

Paediatric Neurosurgery and Neuroradiological* Departments. Hospital Infantil Doce de Octubre. Madrid.

\section{Summary}

Objects. Craniopharyngeal Canal is a rare malformation of the sphenoid bone described in up to $0.42 \%$ of the asymptomatic population. It's been related to the development of the Rathke's pouch during embrionary period although some authors think it's a vestige of a former vascular channel.

Methods. This report details a case of a four and a half years old child that developed recurrent meningitis associated with this anomaly. Its origin, clinical manifestations and treatment options are discussed.

Conclusion. Due to its low incidence and diagnostic difficulties, a high suspicion index is required while studying a case of recurrent meningitis or CSF leakage. Surgical approach is still controversial.

KEY WORDS: Sphenoid bone. Encephalocele. Transcranial approach. Transpalatal approach. Pituitary.

Meningitis de repetición y canal craneofaríngeo persistente: a propósito de un caso

\section{Resumen}

Objetivos. El Canal Craneofaríngeo es una rara malformación del esfenoides que ha sido descrito hasta en el $0,42 \%$ de la población asintomática. Se le ha relacionado con la formación de la Bolsa de Rathke durante el desarrollo embrionario aunque existen autores que opinan que se trata de un vestigio de un canal vascular primitivo.

Métodos. Presentamos el caso de un niño de cuatro años y medio que desarrolló un cuadro de meningitis de repetición asociado a esta anomalía. Revisamos la literatura para discutir su formación, manifestaciones clínicas y opciones de tratamiento.

Conclusión. Dada su baja incidencia y las dificultades diagnósticas es necesario un alto índice de sospecha

Recibido: 11-07-07. Aceptado 19-09-07 durante el estudio de un caso de meningitis de repetición o fístula espontánea de líquido cefalorraquídeo. Existe una gran controversia en lo referente al abordaje quirúrgico idóneo

PALABRAS CLAVE: Esfenoides. Encefalocele. Abordaje transcraneal. Abordaje transpalatal. Glándula hipófisis,

\section{Introduction}

Craniopharyngeal Canal Persistence is an infrequent anomaly in sphenoid bone development which origin some authors relate to Rathke's pouch route while ascending to the sella turcica ${ }^{4,5,8,13}$ while some others think that it is a vestige of a former vascular channel during the ossification of the sphenoid bone ${ }^{1,15,17}$. Currarino ${ }^{4}$ described two different kinds according to its size and its tendency to present as transsphenoidal encephalocele and to be associated to face anomalies, mainly in midline structures such as hyperthelorysm or cleft palate.

The diagnosis requires a high index of suspicion and an exhaustive radiological survey. Management remains controversial in treatment indications as in the optimal surgical approach.

We report the case of a young boy with recurrent meningitis in the presence of this anomaly. When reviewing the literature it's described the controversy associated to its origin, content, clinical manifestations and treatment options.

\section{Case report}

A four and a half years-old boy who had suffered from previous meningitis episode ten months before was admitted in the Emergency Room presenting a new episode of meningitis with blood cultures positive to $S$. pneumoniae. Physical exam did not demonstrate any significant finding. A detailed immunological investigation (white cell count, lymphocyte subset analysis and CD4 and CD8 populations and concentration of immunoglobulins and complement) was unremarkable and radiological studies (CT scan and isotopic cysternography) failed to show any abnormality. The 

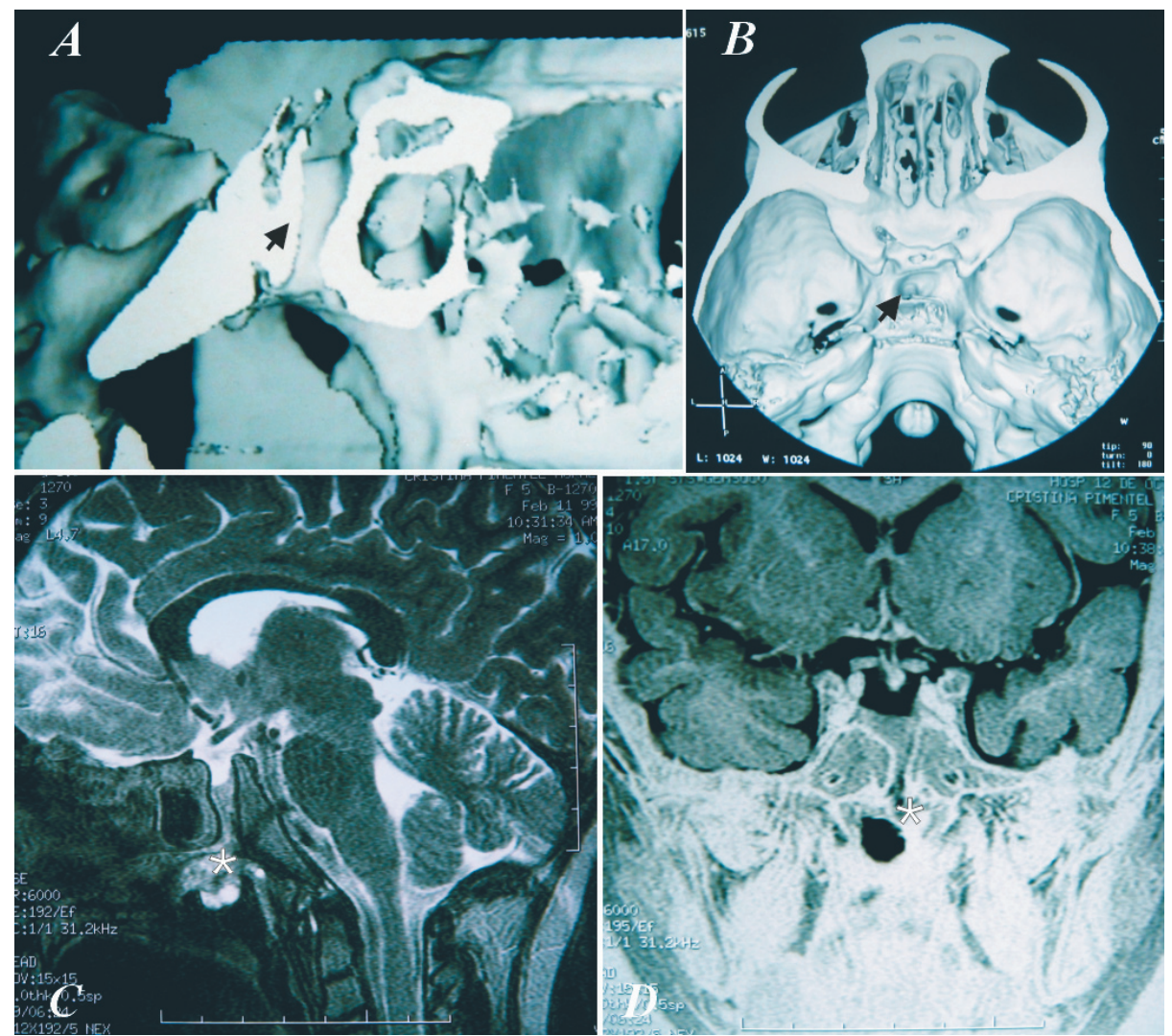

Figure 1. $A$ and B: Preoperative CT scan. Oval shaped channel up to $13 \mathrm{~mm}$ in transverse diameter down from the sphenoid floor crossing the body of the sphenoid bone (black arrows). C and D: Preoperative MRi. Meningocele inside the defect down to the posterior wall of the nasopharynx with intracranial content inside (asterisks).

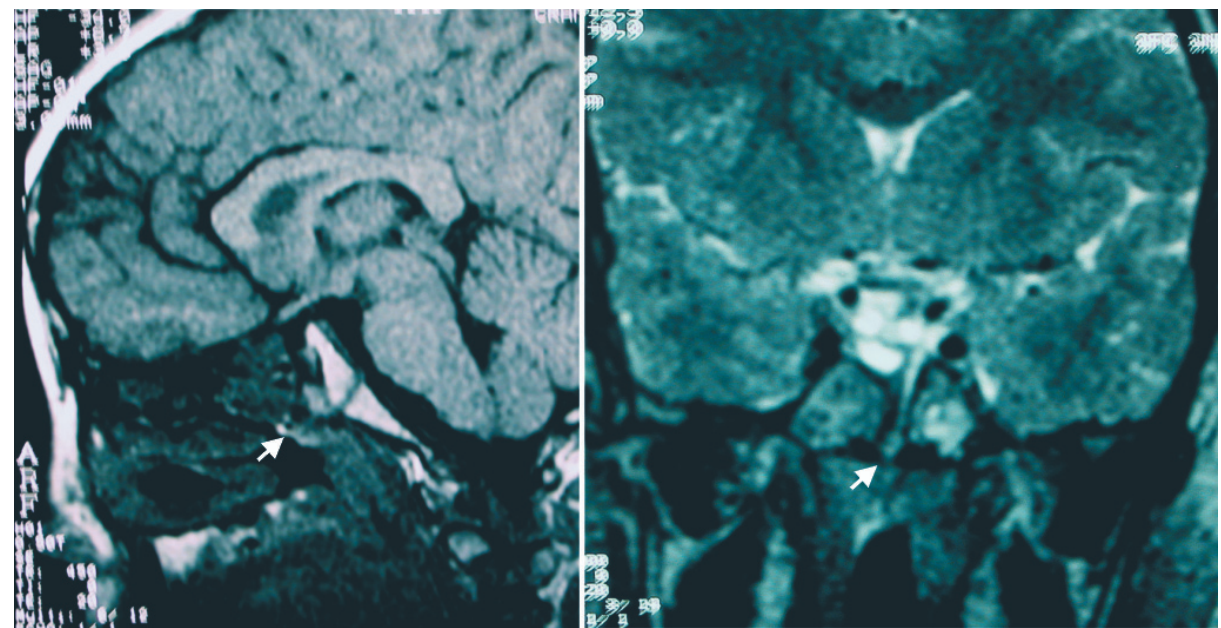

Figure 2. Postoperative MRi. Closure of the defect and reduction of the meningeal sac (white arrows).

patient was discharged after complete recovery, was vaccinated against $S$. pneumoniae and received antibiotic prophylaxis during ten months, after which it was interrupted. Two months later he was readmitted with a similar episode although no organism could be isolated in the different cultures. New immunological examination only showed a slightly reduced cellular reaction against $S$. pneumoniae, reason why he was transfered to our Institution to complete immunologic and radiological examination. A new CT scan showed an oval shaped channel up to $13 \mathrm{~mm}$ in transverse diameter crossing the body of the sphenoid bone to the nasopharynx, compatible with persistence of Craniopharyngeal Canal (Fig 1A-1B) and in the MRI a meningocele could be seen inside the defect down to the posterior wall of the nasopharynx and the pituitary gland inside the body of the sphenoid bone (Fig. 1C-1D). Endocrinological studies failed to show any deficit. Repairing of the defect and reduction of herniated tissue was carried out through a transoral transpalatal approach packing sphenoid sinus floor with autograft bone and reapproximation of the overlying mucosa. Follow-up MRI evaluation showed the closure of the defect and the proper reduction of the meningeal sac (Fig. 2). After two years follow-up, the 
patient remains asymptomatic.

\section{Discussion}

Basal encephaloceles represent up to the $10 \%$ of all encephaloceles with an incidence of approximately 1 in every 35000 live births ${ }^{21,24}$. According to the classification reported by Suwanwela and Suwanwela in $1972^{25}$ and modified by Gerhardt et al in $1979^{7}$, they are subdivided into four subtypes: transethmoidal, sphenoethmoidal, transsphenoidal and sphenoorbital.

Transsphenoidal subtype is the most infrequent of all, being only up to $5 \%$ with an annual incidence of 1 every 700000 live births ${ }^{6,21,24}$. Pollock ${ }^{22}$ proposed several etiopathogenic theories attempting to explain its formation: failure of fusion of ossification centers, raising of intraventricular pressure with progressive erosion of the underlying bone, failure of separation of ectodermal elements from those of the neural creast avoiding mesodermic tissue formation and persistent cranyopharyngeal canal.

Persistent Craniopharyngeal canal is a rare entity first described by Landzert et al in $1868^{20}$, that has been reported in 5 to $10 \%$ of live births ${ }^{20}$ and up to $0.42 \%$ of asymptomatic population ${ }^{1}$. It consists of an oval or circular shaped bony channel that crosses the body of the sphenoid bone from the midline of the floor of the sella turcica down to the nasopharynx in the junction of the vomer with the sphenoid rostrum ${ }^{17,20}$. During the embryological development of the sphenoid bone, the channel is described as located in the junction of the basipresphenoid and the basipostsphenoid ${ }^{8,17,18,20}$, closing at the end of the $10^{\text {th }}$ week of embrionary development ${ }^{20}$. Currarino et $\mathrm{al}^{4}$ divided this anomaly into two different subtypes according to its size: the hypophyseal Channel or Small Craniopharyngeal Canal, with a maximum width up to $15 \mathrm{~mm}$ and the large Craniopharyngeal Canal or Transsphenoidal Channel, related more frequently to other skull base malformations (encephaloceles) and midline facial anomalies (hyperthelorysm, cleft palate and lips,...)

Regarding to its etiology, there exist a great controversy. Some authors defend the hypothesis that it represents the remnant of the ascending track followed by Rathke's pouch through the sphenoid bone from the nasopharynx up to the sella turcica $a^{5,8,13,20,28}$. This hypothesis is supported by histological studies that describe the presence of normal and tumoral pituitary tissue inside the channel ${ }^{20}$, by case reports of panhypopituitarism following adenoidectomy ${ }^{8,13,28}$, by Erdheim's theories and the case reports of infrasellar or nasopharyngeal craneopharyngiomas associated with this anomaly ${ }^{3}$, and by the presence of trans and intrasphenoidal encephaloceles ${ }^{22,23,27}$ or by case reports of intrasphenoidal pituitary tissue in asymptomatic population ${ }^{13,19}$. On the other hand, some authors are opposed to this hypothesis based on anatomical studies that describe as habitual content of the conduit an artery and several small veins (similar to the venae vasis vertebrae) inside a connective tissue, concluding that this so called craniopharyngeal canal represents only the persistence of a vascular channel formed during the osteogenesis of the sphenoid bone $e^{1,15,17,18}$.

We have found 14 cases reported in the recent literature. The most frequent symptoms are related to pituitary malfunction due to compression of the gland ${ }^{5,20}$ or to unintended hypophysectomy after adenoidectomy because of respiratory distress ${ }^{8,28}$. Richter et $\mathrm{al}^{23}$ reported a case of recurrent meningitis after pharyngeal mass resection. There are some case reports as asymptomatic finding 4 or associated to tumors as craneopharyngiomas ${ }^{3}$ o hypothalamic hamartoma ${ }^{5,12}$. We are presenting the case of a patient suffering from recurrent meningitis of uncertain origin associated to this malformation without evidence of CSF leakage or related anomalies.

Literature describes the treatment of this malformation in the same context of the managing of the transsphenoidal encephaloceles. Most of the authors agree in the need of surgical repair in the cases showing rhinorrhea, recurrent meningitis or respiratory distress due to pharyngeal mass $^{10,11,14,29}$. It seems to be more controversial when planning the ideal treatment of an asymptomatic case, when associated to pituitary malfunction or established visual defects $^{10,11}$. According to the surgical approach there are two different options, transcranial and transoral-transpalatal; every case must be individualized according to the anatomy, the contents inside the conduit and the craneofacial anomalies associated. The transcraneal route allows a good reposition of the herniated tissue and the closure of the bony defect with a periostial flap with or without frontal bone fragment ${ }^{14,27}$. It's been related to a morbidity up to $70 \%$ and a mortality up to $50 \%{ }^{10,11,14,29}$, mainly due to herniated tissue resection and unintended hypophysectomy or CSF leakage. However, it has been recently reported some series with good outcomes after transcraneal repair of transsphenoidal encephaloceles ${ }^{27}$. The Transoral-Transpalatal approach, through a minimally invasive procedure, allows the closure of the defect and the repair of the mucosal plane, being necessary some kind of relaxation of the dural sac by fenestration or CSF diversion ${ }^{10,11}$. The main risks related to this approach are infection, CSF leakage and the lack of control of the herniated tissue $\mathrm{e}^{10,11,14}$. In many cases, as a cleft palate can be found as well, the surgical approach becomes easier, being this one of the reasons for many authors to use the Transpalatal approach as the elective route ${ }^{6}$. Recently, some authors have advocated about the use of endoscopic techniques for the repair of transsphenoidal encephaloceles and CSF leaks with good outcomes reported ${ }^{15,26}$.

\section{Conclusions}

Persistence of the Craniopharyngeal Canal is a rare anomaly of the skull base frequently associated with the 
etiology of the transsphenoidal encephaloceles. Due to its low incidence and diagnostic difficulties, a very high suspicion index is required while studying a case of recurrent meningitis or spontaneous CSF leakage. The surgical indications and approach remain controversial making each case an individual challenge according to the anatomical variations, clinical manifestations and anomalies associated.

\section{References}

1. Arey, L.B.: The craniopharyngeal canal reviewed and reinterpreted. Anat Rec.: 1950; 106: 1-16.

2. Bowdler, J.D.: Persistence of the so-called craniopharyngeal canal. J Anat.: 1971; 110: 509.

3. Chen, C.J.: Suprasellar and infrasellar craniopharyngioma with a persistent craniopharyngeal canal: case report and review of the literature. Neuroradiology: 2001; 43: 760-762.

4. Currarino, G., Maravilla, K.R., Salyer, K.E.: Transsphenoidal canal (large craniopharyngeal canal) and its pathologic implications. Am J Neuroradiol: 1985; 6: 39-43.

5. Ekinci, G., Kilic, T., Baltacioglu, F., Elmaci, I., Altun, E., Pamir, M.N., Erzen, C.: Transsphenoidal (large craniopharyngeal) canal associated with a normally functioning pituitary gland and nasopharyngeal extension, hyperprolactinemia, and hypothalamic hamartoma. Am J Roentgenol.: 2003; 180:76-77.

6. Formica, F., Iannelli, A., Paludetti, G., Di Rocco, C.: Transsphenoidal meningoencephalocele. Childs Nerv Syst.: 2002; 18: 295-298.

7. Gerhardt, H.J., Muhler, G., Szdzuy, D., Biedermann, F.: Therapy problems in sphenoethmoidal meningoceles. Zentralbl Neurochir.: 1979; 40: 85-94.

8. Hughes, M.L., Carty, A.T., White, F.E.: Persistent hypophyseal (craniopharyngeal) canal. Br J Radiol.: 1999; 72: 204-206.

9. Jabre, A., Tabaddor, R., Samaraweera, R.: Transsphenoidal meningoencephalocele in adults. Surg Neurol.: 2000; 54: 183-187.

10. Kai, Y., Nagahiro, S., Yoshioka, S., Ushio, Y.: Application of the skull base technique to the repair of transsphenoidal meningoencephaloceles. Pediatr Neurosurg.: 1996; 25: 54-56.

11. Kennedy, E.M., Gruber, D.P., Billmire, D.A., Crone, K.R.: Transpalatal approach for the extracranial surgical repair of transsphenoidal cephaloceles in children. J Neurosurg.: 1997; 87: 677-681.

12. Kizilkilic, O., Yalcin, O., Yildirim, T., Sener, L., Parmaksiz, G., Erdogan, B.: Hypothalamic hamartoma associated with a craniopharyngeal canal. Am J Neuroradiol.: 2005; 26:65-67.

13. Kjaer, I., Russell, B.G.: The craniopharyngeal canal indicating the presence of pharyngeal adenopituitary tissue. Eur J Radiol.: 1995; 20: 212-214.

14. Lewin, M.L.: Sphenoethmoidal cephalocele with cleft palate: transpalatal versus transcranial repair. Report of two cases. J Neurosurg.: 1983; 58: 924-931.

15. Lopatin, A.S., Kapitanov, D.N., Potapov, A.A.:
2009; 20: A-B

Endonasal endoscopic repair of spontaneous cerebrospinal fluid leaks. Arch Otolaryngol Head Neck Surg.: 2003; 129:859-863.

16. Lowman, R.M., Robinson, F., McAllister, W.B.: The craniopharyngeal canal. Acta Radiol Diagn (Stockh): 1966; 5: 41-54

17. Madeline, L.A., Elster, A.D.: Postnatal development of the central skull base: normal variants. Radiology.: 1995; 196: 757-763

18. Madeline, L.A., Elster, A.D.: Suture closure in the human chondrocranium: CT assessment. Radiology.: 1995; 196: 747-756.

19. Marsot-Dupuch, K., Smoker, W.R., Grauer, W.: A rare expression of neural crest disorders: an intrasphenoidal development of the anterior pituitary gland. Am J Neuroradiol.: 2004; $25: 285-288$.

20. Meder, J.F., Melanson, D., Ethier, R.: Persistent craniopharyngeal canal. Apropos of 3 radiologic studies. J Neuroradiol.: 1983; 10: 265-274.

21. Nager, G.T.: “Cephaloceles". Laryngoscope: 1987; 97: 77-84.

22. Pollock, J.A., Newton, T.H., Hoyt, W.F.: Transsphenoidal and transethmoidal encephaloceles. A review of clinical and roentgen features in 8 cases. Radiology: 1968; 90:,442-453.

23. Richter, E., Pirsig, W., Tanzer, A.: A persistent craniopharyngeal canal combined with a meningoencephalocele. HNO: 1975; 23: 240-245.

24. Smith, D.E., Murphy, M.J., Hitchon, P.W., Babin, R.W., Abu-Yousef, M.M.: Transsphenoidal encephaloceles, Surg Neurol.: 1983; 20: 471-480.

25. Suwanwela, C., Suwanwela, N.: A morphological classification of sincipital encephalomeningoceles. J Neurosurg.: 1972; 36: 201-111.

26. Tosun, F., Carrau, R.L., Snyderman, C.H., Kassam, A., Celin, S., Schaitkin, B.: Endonasal endoscopic repair of cerebrospinal fluid leaks of the sphenoid sinus. Arch Otolaryngol Head Neck Surg.: 2003; 129: 576-580.

27. Tsutsumi, K., Asano, T., Shigeno, T., Matsui, T., Ito, S., Kaizu, H.: Transcranial approach for transsphenoidal encephalocele: report of two cases. Surg Neurol.: 1999; 51: 252-257.

28. Weber, F.T., Donnelly, W.H. Jr, Bejar, R.L.: Hypopituitarism following extirpation of a pharyngeal pituitary. Am J Dis Child.: 1977; 131: 525-528.

29. Yokota, A., Matsukado, Y., Fuwa, I., Moroki, K., Nagahiro, S.: Anterior basal encephalocele of the neonatal and infantile period. Neurosurgery.: 1986; 19: 468-478.

Pinilla-Arias, D.; Hinojosa, J.; Esparza, J.; Muñoz. A.: Recurrent meningitis and persistence of craniopharyngeal canal: case report. Neurocirugía 2009; 20: A-B.

First author address: David Pinilla Arias. Neurosurgery Department. Hospital Gregorio Marañón. Doctor Esquerdo, 46. 28007 Madrid 